\title{
Government R \& D Subsidies, Political Relations and Technological SMEs Innovation Transformation
}

Feifei Yu

Business School of Hohai University, Nanjing, China.

Email: yufeifeihhu@gmail.com

Received July, 2013

\begin{abstract}
This paper studies the effect of government research and development (R\&D) subsidies and political relations on the innovative activities of technological small and medium-sized enterprises (SMEs). Moreover, the technology innovation path of SMEs is an important issue related to government R\&D subsidies. This paper explores these effects using multiple case studies. Through case analyses of four biological pharmaceutical enterprises, we found that first, technological SMEs that receive a significant amount of government R\&D subsidies will transform from exploitative innovation to explorative innovation in a short amount of time, whereas technological SMEs that receive less government R\&D subsidies will perform less innovative activities over a long time. Second, technological SMEs with strong political relations tend to do more explorative innovation, whereas technological SMEs with weak political relations tend to do more exploitative innovation. Third, technological SMEs with strong political relations will promote the positive effect of government R\&D subsidies on their innovation performance.
\end{abstract}

Keywords: Government R\&D Subsidies; Technological SMEs; Technological Innovation; Political Relations

\section{Introduction}

As the main force behind national innovation, technology innovation is an important contributor to sustainable development for technological small and medium-sized enterprises (SMEs). However, due to the limitations of scale, lack of resources, and relationships with other enterprises or government departments that are neither close nor stable, technological SMEs need to leverage the support of government departments in the innovation and development process. Since 2008, technological SME clusters have collapsed in some provinces in China due to the financial crisis. Therefore, the State Ministry of Science and Technology, Department of Small and Medium-sized Enterprises, Provincial Department of Science and Technology, and other relevant government departments have introduced a variety of supporting policies to increase the different levels of innovation funds and technology projects for technological SMEs. Thus, how government R\&D subsidies affect the R\&D activities of technological SMEs as well as the shift of the technological innovation path is an important issue related to the government-sponsored effect and technological innovation activities.

In exploring the effect of government subsidies on the self-R\&D of enterprises, foreign scholars remain skeptical of these relations. Several representative viewpoints can be used. First, government subsidies stimulate enterprises self-R\&D by enterprises. For example, according to the data on Israeli manufacturing enterprises in the 1990s, Saul (2002)[1] reported that funds from the Ministry of Industry and Trade promote long-term R\&D investment. Feldman and Kelley (2006)[2] also revealed that enterprises that received government subsidies were more willing to cooperate with others, and funded enterprises tend to obtain other sources of funding compared to others that have not yet been funded. Moreover, Koga (2005)[3] verified that government R\&D subsidies supplement self-R\&D investment based on data from 223 Japanese high-tech entrepreneurial enterprises. Second, government $R \& D$ subsidies have crowding-out effects on the enterprises self-R\&D investment (Goolsbee, 1998[4]; Kelette, Moen, \& Grilichesz, 2000[5]).

Third, no causal relations exist between government R\&D subsidies and self-R\&D investment. For example, Wallsten (2000)[6] asserted that government R\&D subsidies are associated with R\&D investment, but could not prove a causal relationship between the two. He also argued that the more people enterprises employed, the more R\&D activities they performed to win more government $R \& D$ subsidies.

In recent years, the government attached great importance to technical innovation and increased government subsidies, and domestic scholars began to pay attention 
to this issue. In addition, Gao (2011; 2012) demonstrated the influence of different stages of the enterprise life cycle on government R\&D subsidies for technological SMEs. Most domestic scholars studied large- and medium-sized enterprises, demonstrating the relationship between Chinese government $R \& D$ subsidies and selfR\&D investment of large and medium-sized enterprises utilizing regional statistical data from a macro level $(\mathrm{Li}$ Ping, 2010; Wang Chunhui, Cheng Hua, Zhao Xiang, 2009; Cheng Hua, 2008).

In existing research, domestic studies mostly concentrated on the macro level and descriptive illustration, which lack data from an enterprise perspective. Thus, the relevance to technological SMEs was low. Meanwhile, foreign research focused on the relationship between government $R \& D$ subsidies and self-R\&D investment from the economics theory background of market failure, and few studies on the effect of government $R \& D$ subsidies on the specific activities of enterprise technological innovation are available.

In summary, this paper studies Chinese technological SMEs and explores the effects of government R\&D subsidies on the technological innovation path of SMEs, which supplements current domestic and foreign research. This paper is structured as follows: First, we review the relevant literature and put forward three propositions. Then, we introduce research and design details, including the case study method, the selection of cases, and four basic case descriptions. Cross-case analysis on four enterprises selected from biological medicine industry is also included. Finally, we summarize the research conclusion and the limitations of the paper.

\section{Literature Review and Propositions}

\subsection{Government Subsidies Funding Effect: Behavioral Additionality}

Aside from the effect of government R\&D subsidies on R\&D investment and innovation performance, Buisseret et al. (1995)[7] advocated to understand its additionality from a broader sense and recommended the inclusion of the changes in enterprises innovation activities and technology innovation strategy when estimating the spillover effects of government subsidies. Behavior additionality brought by government R\&D subsidies refers to corporate successor management behavior change after obtaining government R\&D subsidies (Davenport et al., 1998)[8]. Behavior additionality revealed most of the changes in enterprises behaviors in the R\&D process.

Several foreign scholars have also pointed out that government $\mathrm{R} \& \mathrm{D}$ subsidies could accelerate the project process, promote the expansion of scale and scope of the project, and encourage enterprises to undertake more challenging research projects. For example, Hsu, Horng, and Hsueh (2009)[9] explored the effect of government $R \& D$ subsidies on the strategic change of R\&D behavior of the recipients, and reported that enterprises sponsored would increase project investment, strengthen strategic implementation, reduce cost, and stimulate commercialization. Therefore, similar to small-scale SMEs with scarcity of R\&D resources, technological SMEs funded by government R\&D subsidies also have innovative behavior additionality. Therefore, we propose:

Proposition 1: Different types and strengths of government R\&D subsidies will influence the innovation path of technological SMEs.

\subsection{Effect of Political Relations on Technological Innovation: Social Capital Perspective}

Although similar in size and industrial characteristics, the differences of technological SMEs in terms of foundation and background are evident. For example, in terms of ownership, technological SMEs have a variety of forms, such as state-owned, joint ventures, and private. Based on their founding background, some SMEs were developed from family enterprises, some were reformed from school-run enterprises, and some were established by several professional technical personnel. Thus, technological SMEs with different foundations and backgrounds will cause enterprises to have different political relations, which affect the direction and specific path of technological innovation.

Social capital is extremely important for enterprise development and innovation due to the small scale of SMEs. Several studies support the opinion that entrepreneurs' social relations have a positive influence on enterprise innovation activities. For example, Zou and $\mathrm{Ni}$ (2010) revealed that the political relations of managers positively influence innovation performance through organizational learning. However, private entrepreneurs' political relational capital has a significantly negative effect on enterprises' R\&D investment tendency and intensity. Thus, other researchers demonstrated an opposite viewpoint. For example, Chen (2012) suggested that private entrepreneurs' political relations and association relations had a significantly negative effect on their $R \& D$ investment intensity.

Political relations are not only an important factor for enterprises technological innovation, but also an important resource. Most scholars believe that a positive relationship exists between political relations and technical innovation, such as Wang, Su, and Chen (2011). However, some scholars hold the opposite view, such as Liu and Yang (2012).

Compared to private enterprises without political association, private enterprises with political association have less R\&D investment based on the data of 101 private corporations with $\mathrm{R} \& \mathrm{D}$ expenditure report disclo- 
sures from the Shenzhen SME board. Moreover, Liang, $\mathrm{Li}$, and Guo (2011) revealed that the informal system protection effect of innovation has a significant difference according to different enterprise technology intensities. In addition, some scholars study the mechanism of the effect of current political relations on enterprise innovation performance. Zeng and Song (2011) argued that political connections do not have a direct effect on innovation performance through an empirical study, indirectly improving performance through intermediary variables of organizational learning and dynamic capabilities.

Based on the above studies, this paper proposes the following:

Proposition 2: The political relations of technological SMEs will affect the selection of their innovation path.

Proposition 3: The political relations of technological SMEs will strengthen the effect of government R\&D subsidies on their technology innovation performance.

\section{Cross-Case Analysis}

\subsection{Government R\&D Subsidies and Innovation Path Selection}

The differences between explorative innovation and exploitative innovation lie in the innovation bases, innovative product, market development, and the source of innovation. Through case analysis, we found that technological SMEs that received more government R\&D subsidies will transform from exploitative innovation to explorative innovation in a relatively short period of time.

Among the four case enterprises, $\mathrm{S}$ company is the one that obtained the largest amount of government R\&D subsidies. S company is a market-oriented R\&D innovation enterprise. Since being listed in 2004, the R\&D intensity of S company reached more than $10 \%$. The company gave much importance to continuously developing new products. R\&D investment increased yearly, and the proportion of $R \& D$ cost remained at $15 \%$ in nearly three years, which was the same as the R\&D investment of multinational pharmaceutical companies. From 2004 to 2005, S company was funded approximately one million Yuan by government R\&D subsidies. After 2007, S company's research project received national support, and government R\&D subsidies rapidly grew to 8.58 million Yuan. In 2010, the received fund was approximately 37.15 million Yuan from 24 funds to reach the high peak.

During listing in 2005, S company extensively developed existing projects and focused on a combination of creation and imitation. In 2005, S company launched a total of nearly 40 new drugs in three major categories and refined company products, forming several product lines with significant features.
Year 2007 is an important turning point for S company in terms of technological innovation. S company adjusted from a combination of imitation and creation to increase the development of innovative drugs, which advocated the steady move with blue ocean strategy through a focus on high-end products and intellectual property. At the same time, S company actively expanded to the international market. In 2007 alone, S company completed applications for seven invention patents and obtained four patent licenses. Since shifting from exploitative innovation to explorative innovation in 2007, S company has become actively involved in new frontiers and strengthened cooperation with domestic and foreign research institutions to constantly develop innovative drugs with huge potential in domestic and foreign markets. For example, in April 2008, S company acquired RuiKang Pharmaceutical Equity and signed a technology transfer contract to strengthen cooperation in R\&D and production with domestic and foreign enterprises. In 2009, S company invested 10.2 million Yuan to set up a joint venture named Liaoning Maidi Technology Co. Ltd., which can extend the industrial chain to new fields, such as vitro and clinical immunology, biochemistry diagnosis reagent, biological treatment and clinical examination, and medical service. In 2010, S company invested 10 million Yuan in Jiangyin Changfeng Medical Technology Ltd. to strengthen its R\&D capability in the field of respiratory systems. In 2011, S company went out of the country and began to pay attention to strengthening cooperation with overseas pharmaceutical companies and research institutions. To quickly enter the field of high-end vaccines and monoclonal antibodies to broaden its business scope, S company cooperated with Canada's Pnu Vax Incorporated to set up a joint venture company, which mainly engaged in R\&D for new vaccines and antibody production and sales. To improve the company's research capability and make full use of drugs from International Research Institutes, S company intended to set up a joint venture named DT with Lin Chai, which engaged in $\mathrm{R} \& \mathrm{D}$ on diabetes prevention or treatment drugs.

Second, technological SMEs that accessed less government R\&D subsidies will remain in the exploitative innovation over a long period of time, or will do less innovative activities. Among the four case firms, $\mathrm{H}$ company obtained the least government R\&D subsidies in nearly three years. Since being listed in 2006, the R\&D intensity of $\mathrm{H}$ company remained at $3 \%$ to $4 \%$. From 2006 to 2008, government R\&D subsidies were always below 2 million Yuan. In 2009, government R\&D subsidies remained below four million Yuan. In 2010, government R\&D subsidies had a breakthrough and reached over seven million Yuan. Moreover, H company authorized two patents in 2008 and another two patents 
in 2010

Overall, the innovative results of $\mathrm{H}$ company were insignificant, which remained in the initial stage of improving management and innovation efficiency as well as organizing the technological innovation department. From 2006 to 2008, H company focused on improving internal management, and its technological innovation depended mainly on the combination of entrust research and joint research. Since 2009, H company has started cooperation with international pharmaceutical companies and built related research institutions and an intellectual property protection department. For example, $\mathrm{H}$ company cooperated with international pharmaceutical companies and had two products that obtained COS and FDA certifications in 2009. H company also set up technological subsidiaries in Shanghai and established an intellectual property department.

\subsection{Political Relations and Selection of Technological Innovation Path}

Political relations are special relations between enterprises and government or politicians, which are beneficial for enterprises to obtain economic benefits from the government. In this paper, we describe political relations with each political association in three aspects: NPC deputies and members, former government officials, and industrial associations.

As a reformed school-run technological SME, D company is a leading bio-pharmaceutical high-tech enterprise mainly operating with molecular diagnostic techniques. D company is the only school-run enterprise listed in Guangdong Province.

From the composition of board members in 2011, nine people are on the board of directors; five of them have a doctorate degree, two of them have an overseas education background, and six of them have working experience in research institutes. Two of the board members have political relations with the municipal People's Congress, one of the board members once worked as a cadre in the national government, and three of them served as executive director of the national government, vice president, or deputy secretary in industry associations. Overall, D company has strong political relations.

Given its unique foundation and strong social background, D company was in an advantageous position in research and application for molecular biology technology, especially in gene diagnosis technology. In the field of fluorescent quantitative PCR detection, D company is the undisputed pioneer and leader and has always focused on explorative innovation. From its technological innovation development, as early as in 1997, D company first achieved the synthesis, labeling, and purification of the core technology of fluorescence quantitative PCR. In 1999, D company independently studied hepatitis B virus fluorescence detection kit, which received the first domestic new drug certificate and production permit for fluorescence quantitative PCR reagent products.

At present, D company's annual research funds account for $10 \%$ of revenue, which reach the R\&D input level of a large international pharmaceutical company. D Company has undertaken a number of national, provincial, and ministerial level scientific research projects of industrialization, and has a national research center named Biological Engineering Technology Center of the Ministry of Health and Medicine, which mainly studied gene molecular diagnosis. From its innovative achievements, D company rapidly and successfully developed an H1N1 influenza detection kit at the beginning of H1N1 influenza outbreaks, and was awarded 10 medical certificates from the State Food and Drug Administration and obtained two invention patents from the National Patent Bureau. In 2010, D company achieved 10 patents of invention granted by the National Patent Office. In 2011, D company strengthened its independent innovation and used international advanced diagnosis technology to continue to strengthen new product development. In this year, D company obtained 14 invention patents from the National Patent Office and a software copyright.

Similar to D company, S company is also a state-owned SME with many innovation achievements, and is focused on explorative innovation. In 2004, the state-owned assets administration wholly invested in Group Company Ltd., which invested 32.61\% to establish S company. From the composition of its board members, only one member has a doctorate degree, and three members served as president, chairman, and vice chairman of the duties in relevant industry associations of the national government, which has strong political relations with industrial associations.

From the viewpoint of controlling shareholders and actual controllers, $\mathrm{H}$ company is a typical family enterprise formed by a father and a father-in-law. Nine people are on the current board, with only two with Ph.D. degrees, and one member has an overseas education background. Considering that the relations between the current chairman and former chairman are father and son, we added the former chairman's political relations to measure the strength of political relations. One of the board members once served as district and city deputy to the National People's Congress, which has strong political relations, and two individuals have political associations with provincial and national industry associations. Overall, H company's political relations are relatively weak. Therefore, innovative results from $\mathrm{H}$ company are relatively less, with a lower total of number of patents. $\mathrm{H}$ company remained in the stage of improving management and innovation efficiency, which saves costs in constructing a technical innovation department. Its R\&D 
intensity only remained at a relatively low level of $3 \%$ to $4 \%$.

Through a comprehensive analysis of the above cases, technological SMEs with stronger political relations tend to do more explorative innovation with increased R\&D intensity, whereas technological SMEs with weaker political relations tend to do more exploitative innovation with weak R\&D intensity.

\subsection{Government Support, Political Relations, and Technological Innovation Performance}

From the average amount of government subsidies in the last five years, $\mathrm{K}$ company and $\mathrm{D}$ company respectively obtained 19,525,020 Yuan and 17,065,490 Yuan, which is roughly the same. However, their R\&D investment, R\&D intensity, and technological innovation performance are very different.

$\mathrm{K}$ company was launched by Tang Weiguo, $\mathrm{Xu}$ Xiande, and Sha Liwu, who were born in the 1940s. These three actual controllers once served as director, deputy director, and the backbone of scientific research in the reagent institution of $\mathrm{K}$ company. $\mathrm{K}$ company is a typical talent entrepreneurial enterprise. Currently, nine people are on the board, with only one having a doctorate degree, two once served as vice president and director of national and municipal industry associations, and one served as city deputy of the Municipal People's Congress. We can see that K company has relative weak political relations with industrial associations and deputies. Comparing the political relevance between two listing corporations, D company reflected political connections with deputies, former government officials, and government industry associations.

According to the data on the R\&D input of K company, we found that the average amount of self- $R \& D$ investment and government R\&D subsidies of K company in the most recent five years is roughly 20 million Yuan. However, R\&D intensity in the most recent five years is only $3.876 \%$, which is the same as family enterprises like H company.

The number of patents is the real objective measure of technological innovation performance of a company. Comparing patents obtained by K company with D company in nearly five years, we found that D company greatly exceeded $\mathrm{K}$ company both in the number and level of innovation. Based on a comparison of the above cases, under the same amount of government R\&D subsidies, strong political relations can stimulate the positive effect of government $R \& D$ subsidies on the technological innovation performance of technological SMEs.

\section{Conclusions and Limitations}

Based on four case studies and analyses, we obtained several findings as follows:

First, the amount of government subsidies affects the choice of technological innovation path of SMEs: (1) technological SMEs that obtained more government R\&D subsidies will change from exploitative innovation to explorative innovation in a relatively short period of time; (2) technological SMEs that received fewer government $R \& D$ subsidies will remain in exploitative innovation for a long time or will do less innovative activities.

Second, the intensity of political relations will affect the technological innovation activities of SMEs: (1) technological SMEs with stronger political relations will increase R\&D intensity and tend to do more explorative innovation; (2) technological SMEs with weaker political relations will decrease R\&D intensity and tend to do more exploitative innovation.

Finally, with access to the same government $R \& D$ subsidies, technological SMEs with strong political relations will promote the positive effect of government $\mathrm{R} \& \mathrm{D}$ subsidies on the technological innovation performance of technological SMEs.

\section{Acknowledgements}

This paper is financed by Youth project of National Social Science Fund in China, 12CGL010, 2012-2014; Chinese Ministry of education of Humanities and social sciences research Youth Fund Project, 12YJC630273, 2012-2014 and Central University Research Funds of Hohai University, $2013 \mathrm{~B} 12114$.

\section{REFERENCES}

[1] Lach and Saul, "Do R\&D Subsidies Stimulate or Displace Private R\&D? Evidence from Israel,” Journal of Industrial Economics, Blackwell Publishing, Vol. 50, No. 4, 2002, pp. 369-90.

[2] M. P. Feldman and M. R. Kelley, "The Ex Ante Assessment of Knowledge Spillovers: Government R\&D; Policy, Economic Incentives and Private Firm Behavior," Research Policy, Vol. 35, No. 10, 2006, pp. 1509-1521. doi:10.1016/j.respol.2006.09.019

[3] T. Koga, "R\&D Subsidy and Self-Financed R\&D: The Case of Japanese High-Technology Start-Ups. Small Business Economics,” Vol. 24, No. 1, 2005, pp. 53-62. doi:10.1007/s11187-005-3096-z

[4] A. Goolsbee, "Does Government R\&D Policy Mainly Benefit Scientists and Engineers?” American Economic Review, 1998, Vol. 88, pp. 298-302.

[5] T. J. Kelette, J. Moen and Z. Griliches, "Do Subsidies to Commercial R\&D Reduce Market Failures? Microeconomic Evaluation Studies,” Research Policy, Vol. 29, 2000, pp. 471-495. doi:10.1016/S0048-7333(99)00086-4

[6] S. J. Wallsten, “The Effects of Government-Industry R\&D Programs on Private R\&D: The Case of the Small 
Business Innovation Research Program," The RAND Journal of Economics, Vol. 32, No. 1, 2000, pp. 82-100. doi:10.2307/2601030

[7] T. J. Buisseret, H. M. Cameron, et al. "What Difference Does It Make Additionality in the Public Support of RD in Large Firms," International Journal of Technology Management, Vol. 10, No. 4-5, 1995, pp. 587-600.

[8] S. Davenport, C. Grimes, et al., "Research Collaboration and Behavioral Additionality: A New Zealand Case study," Technology Analysis \& Strategic Manage -ment, Vol. 10, No. 1, 1998, pp. 55-68.

[9] F.-M. Hsu, D.-J. Horng, et al., "The Effect of Government-sponsored R\&D Programmes on Additionality in Recipient Firms in Taiwan,” Technovation, Vol. 29, No. 3, 2009, pp. 204-217. doi:10.1016/j.technovation.2008.05.001 